\title{
Evaluation of Career Counsellors' Competences in Career Guidance
}

\author{
Vija Dislere ${ }^{1}$ Dr.paed.; Natalja Vronska ${ }^{2}$ Dr.paed. \\ Latvia University of Life Sciences and Technologies, Latvia \\ vija.dislere@1lu.lv¹; natalja.vronska@1lu.lv²
}

\begin{abstract}
The importance of career guidance and the role of career counsellor is described and highlighted in this article. The aim of the study is to evaluate the importance of career counsellor competencies in the field of career guidance in Latvia, to develop criteria for evaluating career counsellor competence in order to achieve this goal. The self-evaluation of career counsellors regarding their competences was used. In the study 337 respondents were took part from all Latvia regions, they were graduates of the last ten years of the Career Counsellors Master's Program and other in-service career counsellors and school career counsellors working in schools, employment agencies and private consulting companies. The data were analysed statistically by using SPSS computer program: 1) rank transformation, 2) crosstab method, 3 ) chi-squared test. The significance of the results and the most important conclusion: the best developed professional competencies of career counsellors and school career counsellors on criteria Career information competences are knowledge of updated information on employment trends, labour market, and social issues. The best developed sub-competences on criteria Career education competences are to demonstrate the knowledge of lifelong career development process and to use career planning and decision making in training. The three most developed sub-competencies on criteria Career counselling competences are ability to use dialogue in career guidance, exploration competency and use of counselling methods. The three most developed sub-competencies on criteria Career service managing competence are skills to cooperate effectively in a team of professionals, knowledge of (office) politics, networking ability. The three most developed sub-competencies on criteria Generic competence are observing ethical standards, communication and listening and empathy, insight.
\end{abstract}

Keywords: competences, career counsellors, career guidance, career education.

\section{Introduction}

\section{The importance of career guidance and the role of career counsellor}

The rapid changes in the economic and labour market structure, the diversity of study programs and the relevance of education outcomes to the labour market, have led to the development of a system to help individuals better integrate into the education process and into the labour market at national and international levels. Career guidance is implemented through the organization of a range of activities that include career guidance, career education and information on education and on work opportunities as well as on inter-relation between them. The results of the study show that the availability and quality of information about education and job opportunities, involving employers, provided by career counsellors, positively influences the person to choose the education and career path that suits his / her interests and abilities (Jaunzeme, 2011, 126). It shows the importance of career guidance.

Promotion and advocacy of career development for individuals is ensured regardless of age, culture, mental/physical ability, ethnicity, race, nationality, religion/spirituality, gender, gender identity, sexual orientation, marital/partnership status, military or civilian status, language preference, socioeconomic status, any other characteristics not specifically relevant to job performance, in accordance with National Career Development Association policy (Minimum Competencies for..., 2009). It is important to follow to these political principles.

Career education is the systematic collaboration between educational institutions, parents, and the community to help children, adolescents, young people and adults to learn to develop and independently evaluate their careers. Career education is implemented in educational institutions. The development of students' competences in accordance with the requirements of the labour market can be promoted by implementing career education measures and integrating them into higher education studies. Recognizing the importance of career guidance in promoting student employability, more and more Universities in the European Union and Universities of other countries are introducing modular courses or activities to equip 
students with general and career management skills. For example, in the United Kingdom, academic staff, staff of the career centre, social partners and students work closely together to deliver these activities (Gothard et al., 2001; Jaunzeme, 2011, 127). This model defines career services as support for academic departments to integrate employability and career management skills into curriculum content.

Modern education systems help learners to develop emotionally, socially, intellectually and physically (Karataş, Kaya, 2015). Career counsellors help students to develop and to make informed decisions, including career choices. According to K.M. Oertle and S. O'Leary (2017), guidance is about services that help students to solve problems, to make decisions, to improve their abilities and to act responsibly. The individuals that offer and maintain professional counselling services are school counsellors and other qualified experts in counselling. E. Goodman-Scott and T. Grothaus (2017) expound that counsellor' roles have evolved over time and have included mental health counselling, assessment and psychometry, career guidance, coordination, collaboration, and education among others. According to K. Karataş and I. Kaya (2015), counsellors establish vital psychological relationships with individual learners, which help in maintaining their respective development and decision-making (Hanımoglu, 2018). As a result of innovative processes taking place in modern society is developing a new system of educational values. Educational strategies involve the use of an educational competence model that provides the conditions for personality development and growth (Zhanguzhinova, Magauova, Nauryzbaeva, 2016). As a result of scientific research, several models of career guidance have been developed at our Latvia University of Life Sciences and Technologies to improve the content development of the Career Counsellor study program.

J. Pavulens worked out the Career Management Cycle: Constructivist Model (Pavulens, 2015, 334), which is based on the constructivist approach and includes assumptions created on the basis of several theories such as career, learning, activity and project management theory. Career management competence he described as the ability to handle career situations; to mobilize and combine personal and external resources and to use them in the implementation of appropriate activities to achieve the desired results; to cooperate with others and to be able to attract scarce resources; and to learn from experience. Life and career development consist of goal setting, career modelling, testing and optimization of different career models, testing of conditions and resources and finally the realization of the most appropriately selected model. The model suggested by J. Pavulens is recommended for use by a career counsellor.

Guidance Model for Promoting Self-Directed Career Decision-Making by Secondary School Students (Briska, Dislere, 2018, 349) focuses on secondary school students who has inability to make crucial decisions on their future profession as well as to understand themselves, their interests, abilities and needs. Using this model and encouraging action career guidance counsellors and the classroom teachers-counsellors stimulate student initiative through self-study to develop their abilities and skills, to identify their interests and talents, to set learning and career goals, to plan their work and to make responsible decisions.

The Information communication Technologies (ICT)-based Career Guidance Model (Urdzina-Merca, Dislere, 2018, 411) was developed based on both scientists' work experience and previous scientific findings. It is important to integrate the theoretical findings, the latest ICT achievements and the content of career education (professional diversity, labour market requirements and self-presentation skills) and the newest career counselling techniques (the project method, video training and company workshop visits) into career guidance activities. The authors believe that an interaction of the model's all sections: "Theories", "ICT" and "Content" in particular could yield the best outcomes in career guidance for young individuals.

To provide career support to women experiencing professional crisis, A. Racene and V. Dislere have developed the Didactic Model of Crisis Management for Women in Professional Crisis Situations (Racene, Dislere, 2016, 7), the target audience is women wishing or being forced to change their occupation due to a professional crisis. A type of consultation (advising, informative consultation, diagnostic consultation, formative and corrective consultation and e-consultation) is chosen on the basis of customer's wishes or the content of a career consultation. The model provides a methodology for managing a professional crisis, observing the principle of gender conformity in the course of career counselling (compliance with gender equality set in law, application of communication theories, breaking of stereotypes and raising of women's self-confidence). The developed model is recommended to use for career counsellors.

The importance of career counselling has also been studied by several authors. Providing guidance and counselling is both a practical and a theoretical approach, stemming from the social pressures of industrial 
development (Patton, McMahon, 2014). Researchers have developed systems theory and studied the role of theory and practice in career development (Patton, McMahon, 2014). C. Stăiculescu, R. Livinţi, L.R. Ștefan, S. Todea, and N. Albu (2017) studied the aspect of managing the necessity of counselling and career guidance among the students. The researchers indicate that selecting the right profession and then progressing through the required steps to be a specialist is a sophisticated endeavour. They reduce dropouts, foster transition in different education levels, enhance participation, bolster social inclusion, and ensure accessibility to the labour market (Hanımoglu, 2018). Professional career counsellors offer appropriate guidance that are specific to individuals after assessing and testing a learner's intelligence, skills, personality, and interests. There are several conditions that affect a learner's choice of career; hence, it is vital to guide the learners to make informed and appropriate decisions regarding their future career (Hanımoglu, 2018).

R.S. Sharf (2014) has developed and researched career development theories in multiple dimensions, he provides important perspectives that may be useful in counselling, such as, constructivist approach that emphasize understanding clients' perceptions of the world; how individuals are influenced by others in career decision making (Phillips, Christopher-Sisk, Gravino, 2001); how behavioural approaches influences the client. The use of dialogue in career guidance of students of secondary vocational schools helps to build and develops their professional identity. Evolution of dialogue for students' career guidance in secondary vocational education is worked out by I. Soika (2017). Her experience of career guidance has shown that the meanings constructed through dialogue, develops an understanding of career planning and life designing. F. Meijers, M. Kuijpers, C. Gundy (2013) in their studies proved contribution of career dialogue in rising learning motivation, experienced fit of choice with learning tasks and experienced fit of internship.

Sustainable community development is related to the formation and development of new attitude to workplace wellness in educational process (Brizga, Peks, 2014). Workplace wellness includes the following dimensions: social, occupational, spiritual, physical, intellectual and emotional. Workplace wellness is any workplace health promotion activity or organizational policy designed to support healthy behaviour in the workplace including career counsellor workplace.

It follows from the above that the qualifications of a career counsellor are of paramount importance in order to be competent in their profession and able to apply their knowledge of the structure of the labour market and use the opportunities offered by the education system to carry out their professional work. Links between career guidance, demands of labour market and education system are explained in Figure 1.

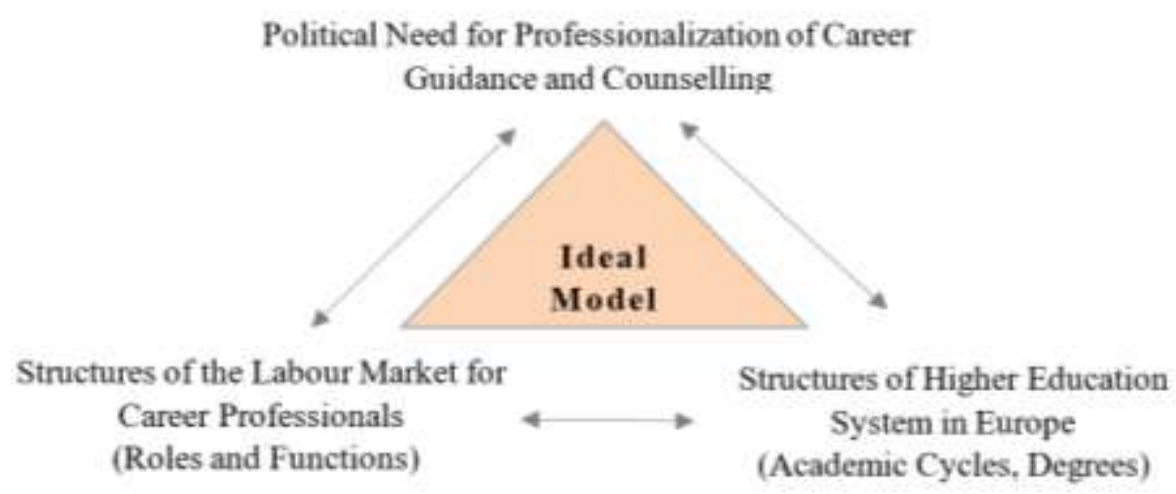

Figure 1. Links between career guidance, demands of labour market and education system (Katsarov et al., 2014).

A career counsellor has to be able to implement a variety of career support models and programmes to provide support to people (schoolchildren, students, adults, the unemployed) in acquiring an education or retraining, in career choices or career changes, to provide consultations, and to be understanding assistants in life choices.

\section{What are the competencies of a career counsellor}

Many scientists have been working on identifying the competencies of career counsellors and exploring their need and importance, also several studies have already been carried out: career counselling from a constructivist perspective, the analysis of school counsellors' activities is based on two directions: a) the choice of intervention strategies in relation to activities specific to the school they work in (middle school, 
theoretical/technological/vocational high school), and b) professional experience (beginners or not) (Axinte, 2014); skills for career counsellor - empathy, insight, communication and listening, flexibility and tolerance (Blank, 2017); core competences - ethical behaviour, advocacy and leadership, awareness and appreciation of clients' cultural differences, integrate theory and research into practice in guidance, implement counselling programmes, awareness of own capacity, language knowledge, knowledge of updated information on educational, training, employment trends, labour market, and social issues, skills to cooperate effectively in a team of professionals, demonstrate knowledge of lifelong career development process (Hiebert, Neault, 2014); The right choice of a method and the interpretation of the counselling result could stimulate the student to make a decision based on his/her values; value identification methods help career counsellors to identify career counselling boundaries as well as act professionally, ethically and wisely in assessing any particular situation and identifying the particular kind of career guidance needed (Racene, Dislere, 2019).

In the counselling process, the counsellor uses a variety of tools, exercises and tasks, including selection and using of diagnostic methods, that aim to broaden the client's self-confidence, create and practice new behaviours and new views to support their informed decision-making. Counselling methods and tools are not aimed at diagnosing, but at building self-awareness and letting the client widely explore himself, his life and his environment, which you can call self-diagnosis (Bielecki, 2013).

The authors C.R. Ridley, D. Mollen and S.M. Kelly (2011) conceptualize counselling competence as more complex and nuanced than do traditional micro-skills models and include cognitive, affective, and behavioural components. The model consists of 4 superordinate competencies-determining therapeutic outcomes, facilitating therapeutic outcomes, evaluating therapeutic outcomes, and sustaining therapeutic outcomes - and 12 subordinate competencies: self-appraisal/ self-evaluating, structuring the therapy, building a therapeutic alliance, applying a conceptual map of therapeutic change, using therapeutic techniques, self-correcting, surmounting obstacles, leveraging opportunities, managing special situations, working with other systems of care, consulting other sources, and terminating therapy. Integral to the model is the integrated deep structure, which consists of 5 metacognitions: purposefulness, motivation, selection, sequencing, and timing.

Career counsellors have distinct personalities. They tend to be social individuals, which means they're kind, generous, cooperative, patient, caring, helpful, empathetic, tactful, and friendly. They excel at socializing, helping others, and teaching. Some of them are also enterprising, meaning they're adventurous, ambitious, assertive, extroverted, energetic, enthusiastic, confident, and optimistic (What does a career..., 2019).

A study on career competences and a factor analytic study on a large sample yielded a seven-factor structure were done based on several competences: goal setting and career planning, self-knowledge, job performance, career-related skills, knowledge of (office) politics, career guidance and networking, and feedback seeking and self-presentation. The results suggested to use this seven-factor criterion for evaluation of the validity of competences (Francis-Smythe et al., 2013).

One of the competencies of career counsellors is ability use an online tool in career counselling, helping people in need of career guidance remotely, they can get career guidance from a career counsellor no matter when or where they are (Rācene, Dišlere, 2014). Nowadays, this method is becoming more and more popular. Also, A. Racene (2017) in her study about importance of goal-setting tasks in career counselling, what was carried out involving vocational school students, revealed that the respondents most often set the following goals: starting a family, starting up a business and becoming a good specialist in the chosen profession. This research contributed to the understanding of importance of goalsetting tasks in career counselling and give insight into youth's goals in their lives. Students develop their abilities to think, to plan and to analyse and to define their life goals.

The ability to reconstruct a client's life portrait is part of a career counsellor's competence- to integrate clients' small stories into a large story, that enriches clients' self-understanding, changes perspective, clarifies what is at stake in the transition, eases decision making, and prompts client action, which is also the most important result (Savickas, 2011). R. Bobu, L. Soitu (2012) describe competences as exploration competency, planning competencies, relationship abilities - respect, motivation, project engagement that should be developed to a superior level regarding the counselled person, through the capacity to build a genuine relationship. Career counsellor roles are facilitator of personal and professional development, consultant for those seeking a job, motivator, information supplier for labour market and 
occupational areas, facilitating customer access to career opportunities in the labour market, designer to initiate development activities of staff in an organisation.

R. Orbé-Austin (2010) offers five key tips to consider when developing a multicultural career counselling competence - cultural career history, outcome expectations, protected careers and self-efficacy, networking ability and awareness of our own cultural biases. Multicultural career counselling competence is always a work in progress, and our goal as career experts should be to maintain a stance of openness to learn and enhancing our knowledge, skills and awareness to adjust to the changing needs of client population (Mani, 2020). A career counsellor should have the ability to respond appropriately to individuals from diverse cultures and populations, and to be able to interact with a client in both individual and group counselling, providing targeted and sensitive support for clients/students in using the information, resources, and technologies, observing ethical standards and using supervision and professional consultations effectively (Minimum Competencies for..., 2009).

The Network for Innovations in Career Guidance and Counselling in Europe (NICE) (Network for Innovations..., 2019) makes a major contribution in working out career counsellor competences. NICE is an open European network for the academic training of people who practice career guidance and counselling (career practitioners). Scientists from this network presents the fields of core competences of career counsellor (Figure 2) (Katsarov et al., 2014).

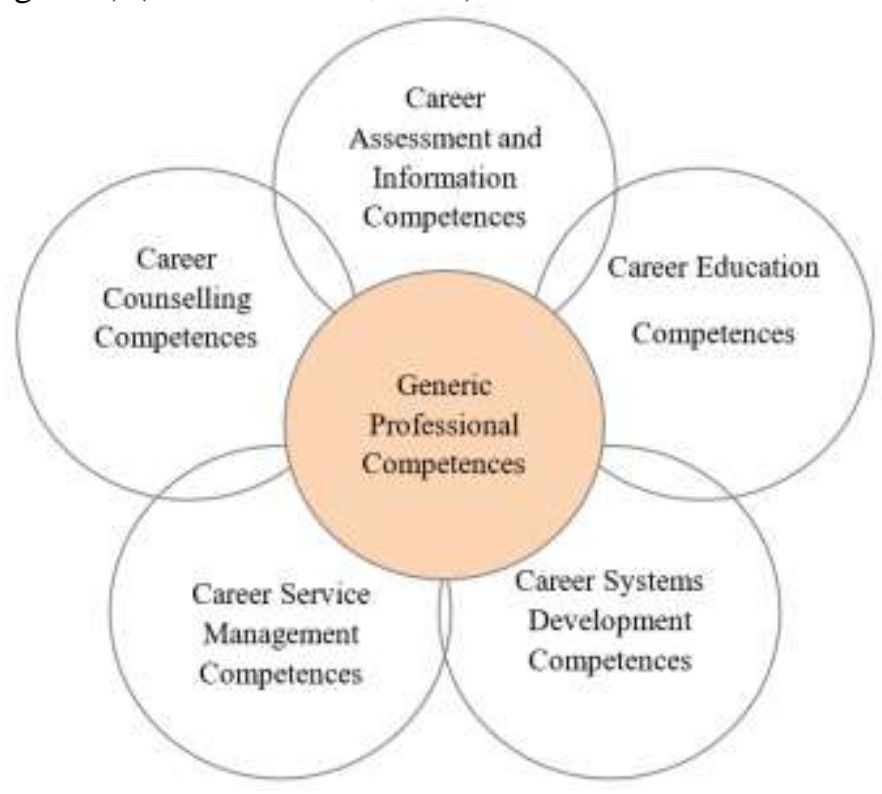

Figure 2. Core Competences should be understood as fields of competence; not as measurable competences (Katsarov et al., 2014).

In compiling and evaluating the scientific findings of the above scientists, the authors developed criteria for assessing the relevance of career counsellor competencies (Table 1).

Table 1

The criteria for assessing the competence of career counsellors

\begin{tabular}{|c|l|l|}
\hline $\mathbf{N}$ & $\begin{array}{l}\text { Criteria field of } \\
\text { competence }\end{array}$ & \multicolumn{1}{c|}{ Sub-competences } \\
\hline 1 & $\begin{array}{l}\text { Career } \\
\text { information } \\
\text { competences }\end{array}$ & $\begin{array}{l}\text { - knowledge of updated information on educational and training } \\
\text { - knowledge of updated information on employment trends, labour market, and } \\
\text { social issues }\end{array}$ \\
\hline \multirow{2}{*}{2} & $\begin{array}{l}\text { Career education } \\
\text { competences }\end{array}$ & $\begin{array}{l}\text { - to integrate the theory and research into practice in guidance } \\
\text { - to use the goal setting tasks in training } \\
\text { - to use career planning and decision making in training }\end{array}$ \\
\hline
\end{tabular}




\begin{tabular}{|c|c|c|}
\hline $\mathbf{N}$ & $\begin{array}{c}\text { Criteria field of } \\
\text { competence }\end{array}$ & Sub-competences \\
\hline 3 & $\begin{array}{l}\text { Career counselling } \\
\text { competences }\end{array}$ & $\begin{array}{l}\text { - exploration competency } \\
\text { - selection and using of diagnostic methods } \\
\text { - use of counselling methods } \\
\text { - to be able to interact with a client in individual counselling } \\
\text { - to be able to interact with a client in group counselling } \\
\text { - ability to use of dialogue in career guidance } \\
\text { - a multicultural career counselling }\end{array}$ \\
\hline 4 & $\begin{array}{l}\text { Career service } \\
\text { managing } \\
\text { competence }\end{array}$ & $\begin{array}{l}\text { - ability to implement a variety of career support models and programmes } \\
\text { - ability to carry out a variety of career support models and programmes } \\
\text { - skills to cooperate effectively in a team of professionals, } \\
\text { - knowledge of (office) politics } \\
\text { - networking ability }\end{array}$ \\
\hline 5 & $\begin{array}{l}\text { Generic } \\
\text { competences }\end{array}$ & $\begin{array}{l}\text { - empathy, insight } \\
\text { - communication and listening, } \\
\text { - flexibility and tolerance } \\
\text { - observing ethical standards } \\
\text { - awareness and appreciation of clients' cultural differences, } \\
\text { - use an online tool in career counselling } \\
\text { - workplace wellness } \\
\text { - awareness of own capacity }\end{array}$ \\
\hline
\end{tabular}

The aim of the study is to evaluate the importance of career counsellor' competencies in the field of career guidance in Latvia, and to develop criteria for evaluating career counsellor competence in order to achieve this goal.

\section{Methodology}

The empirical study was developed at the Latvia University of Life Sciences and technologies at the Institute of Education and Home Economics and conducted in late 2019 and early 2020.

Questionnaires were done via emails and social networks. The questionnaires were sent to graduates of the last ten years of the Career Counsellors Master's Program and other in-service career counsellors and school career counsellors working in schools, employment agencies and private consulting companies in Latvia. For the study 826 questionnaires were sent out, 337 questionnaires were got back; $23 \%$ of respondents are career counsellors, $77 \%$ of respondents are school career counsellors.

Respondents were asked to fill in questionnaires and self-assess their career counsellor competencies according to the criteria developed by the authors (Table 1), where competencies were grouped into 5 fields and several sub-competences were assigned to each field using the scientific findings in the theoretical review. Respondents were asked, what career counsellor competencies do they think they have and to what extent (3-excellent; 2-good;1-poor).

Research tasks:

- to evaluate the importance of career counsellor' competencies in the field of career guidance in Latvia;

- to discover if there is a relationship between two independent samples;

- to analyse the frequency of respondent answers and to find out statistically significant prevalence.

Research methods:

- data collection methods: questionnaire;

- data processing methods:

○ rank transformation (Ranking Data in..., 2020);

- crosstab method (Paura, Arhipova, 2002);

○ chi-square test (Arhipova, Bāliṇa, 2006).

The data were analysed statistically by using SPSS Statistics software. 


\section{Results and Discussion}

The criteria for assessing the relevance of career counsellor competencies were analysed below using rank transformation (Table 2-6).

Highest number of responses to the answer good is in sub-competence "knowledge of updated information on employment trends, labour market, and social issues" (ranked data 216). Highest number of responses to the answer excellent is in sub-competence "knowledge of updated information on educational and training" (ranked data 144). Overall, career information competences are well advanced and only a few respondents ( 24 respondents or $7.1 \%$ and 6 respondents or $1.8 \%$ ) need to improve them (Table 2).

Table 2

Rank transformation of Career information competences

\begin{tabular}{|c|c|c|c|}
\hline \multicolumn{2}{|c|}{ Ranked data } & \multirow{2}{*}{ Answers } & \multirow{2}{*}{ Sub-competences } \\
\hline n & $\%$ & & \\
\hline 216 & 64.3 & good & $\begin{array}{l}\text { knowledge of updated information on employment trends, labour market, and } \\
\text { social issues }\end{array}$ \\
\hline 144 & 42.9 & excellent & knowledge of updated information on educational and training \\
\hline 96 & 28.6 & excellent & $\begin{array}{l}\text { knowledge of updated information on employment trends, labour market, and } \\
\text { social issues }\end{array}$ \\
\hline 85 & 25.3 & good & knowledge of updated information on educational and training \\
\hline 24 & 7.1 & poor & $\begin{array}{l}\text { knowledge of updated information on employment trends, labour market, and } \\
\text { social issues }\end{array}$ \\
\hline 6 & 1.8 & poor & knowledge of updated information on educational and training \\
\hline
\end{tabular}

Highest number of responses to the answer good is in sub-competence "to integrate the theory and research into practice in guidance" (ranked data 243). Highest number of responses to the answer excellent is in sub-competence "to demonstrate the knowledge of lifelong career development process" (ranked data 126). Only 6.5-13.4\% of respondents are required to improve these competences (Table 3 ).

Table 3

Rank transformation of Career education competences

\begin{tabular}{cccl}
\hline \multicolumn{2}{c}{ Ranked data } & Answers & Sub-competences \\
\cline { 1 - 2 } $\mathbf{n}$ & $\boldsymbol{\%}$ & & \\
\hline 243 & 72.1 & good & to integrate the theory and research into practice in guidance \\
202 & 59.9 & good & to use the goal setting tasks in training \\
191 & 56.7 & good & to use career planning and decision making in training \\
187 & 55.5 & good & to demonstrate the knowledge of lifelong career development process \\
126 & 37.4 & excellent & to demonstrate the knowledge of lifelong career development process \\
113 & 33.5 & excellent & to use career planning and decision making in training \\
100 & 29.7 & excellent & to use the goal setting tasks in training \\
47 & 13.9 & excellent & to integrate the theory and research into practice in guidance \\
45 & 13.4 & poor & to integrate the theory and research into practice in guidance \\
32 & 9.5 & poor & to use the goal setting tasks in training \\
30 & 8.9 & poor & to use career planning and decision making in training \\
22 & 6.5 & poor & to demonstrate the knowledge of lifelong career development process \\
\hline
\end{tabular}

Highest number of responses to the answer good is in sub-competence "selection and using of diagnostic methods" (ranked data 208). Highest number of responses to the answer excellent is in sub-competence "ability to use of dialogue in career guidance" (ranked data 127). Overall, career counselling competences are well advanced and only 8.3-27.3\% of respondents need to improve them (Table 4).

Highest number of responses to the answer good is in sub-competence "ability to carry out a variety of career support models and programmes" (ranked data 213). Highest number of responses to the answer excellent is in sub-competence "skills to cooperate effectively in a team of professionals" (ranked data 139). Only 6.2-25.5\% of respondents are required to improve these competences (Table 5). 
Table 4

Rank transformation of Career counselling competences

\begin{tabular}{|c|c|c|c|}
\hline \multicolumn{2}{|c|}{ Ranked data } & \multirow{2}{*}{ Answers } & \multirow{2}{*}{ Sub-competences } \\
\hline n & $\%$ & & \\
\hline 208 & 61.7 & good & selection and using of diagnostic methods \\
\hline 205 & 60.8 & good & exploration competency \\
\hline 202 & 59.9 & good & a multicultural career counselling \\
\hline 184 & 54.6 & good & to be able to interact with a client in group counselling \\
\hline 177 & 52.5 & good & use of counselling methods \\
\hline 176 & 52.2 & good & ability to use of dialogue in career guidance \\
\hline 156 & 46.3 & good & to be able to interact with a client in individual counselling \\
\hline 127 & 37.7 & excellent & ability to use of dialogue in career guidance \\
\hline 119 & 35.3 & excellent & to be able to interact with a client in individual counselling \\
\hline 103 & 30.6 & excellent & to be able to interact with a client in group counselling \\
\hline 102 & 30.3 & excellent & use of counselling methods \\
\hline 92 & 27.3 & excellent & exploration competency \\
\hline 92 & 27.3 & poor & a multicultural career counselling \\
\hline 63 & 18.7 & excellent & selection and using of diagnostic methods \\
\hline 59 & 17.5 & poor & selection and using of diagnostic methods \\
\hline 53 & 15.7 & poor & use of counselling methods \\
\hline 52 & 15.4 & poor & to be able to interact with a client in individual counselling \\
\hline 43 & 12.8 & poor & to be able to interact with a client in group counselling \\
\hline 36 & 10.7 & excellent & a multicultural career counselling \\
\hline 34 & 10.1 & poor & exploration competency \\
\hline 28 & 8.3 & poor & ability to use of dialogue in career guidance \\
\hline
\end{tabular}

Table 5

Rank transformation of Career service managing competence

\begin{tabular}{cccl}
\hline \multicolumn{2}{c}{ Ranked data } & \multirow{2}{*}{ Answers } & \\
\cline { 1 - 2 } $\mathbf{n}$ & $\mathbf{\%}$ & & \multicolumn{1}{c}{ Sub-competences } \\
\hline 213 & 63.2 & good & ability to carry out a variety of career support models and programmes \\
207 & 61.4 & good & ability to implement a variety of career support models and programmes \\
207 & 61.4 & good & networking ability \\
201 & 59.6 & good & knowledge of (office) politics \\
175 & 51.9 & good & skills to cooperate effectively in a team of professionals \\
139 & 41.2 & excellent & skills to cooperate effectively in a team of professionals \\
111 & 32.9 & excellent & knowledge of (office) politics \\
86 & 25.5 & poor & ability to implement a variety of career support models and programmes \\
67 & 19.9 & excellent & networking ability \\
65 & 19.3 & poor & ability to carry out a variety of career support models and programmes \\
58 & 17.2 & poor & networking ability \\
55 & 16.3 & excellent & ability to carry out a variety of career support models and programmes \\
40 & 11.9 & excellent & ability to implement a variety of career support models and programmes \\
22 & 6.5 & poor & knowledge of (office) politics \\
21 & 6.2 & poor & skills to cooperate effectively in a team of professionals \\
\hline
\end{tabular}

Highest number of responses to the answer excellent is in sub-competence "observing ethical standards" (ranked data 262). Highest number of responses to the answer good is in sub-competence "awareness of own capacity" (ranked data 194). Overall, career information competences are well advanced and only a few respondents (5 respondents or $1.5 \%$ and 3 respondents or $0.9 \%$ ) need to improve them (Table 6 ).

Crosstabs method is used to discover if there is a relationship between more independent samples: subcompetences sample and to what extent sample. Null hypothesis: there is not a relationship between two independent samples, while alternative hypothesis: there is a relationship between two independent samples (Table 7-11).

The Pearson Chi-Square p-value $=0.000$ (Table 7), so the null hypothesis must be rejected and the alternative hypothesis accepted. In the criteria Career information competences is a relationship between Sub-competences sample and to what Extent sample. 
Table 6

Rank transformation of Generic competence

\begin{tabular}{|c|c|c|c|}
\hline \multicolumn{2}{|c|}{ Ranked data } & \multirow{2}{*}{ Answers } & \multirow{2}{*}{ Sub-competences } \\
\hline $\mathbf{n}$ & $\%$ & & \\
\hline 262 & 77.7 & excellent & observing ethical standards \\
\hline 235 & 69.7 & excellent & communication and listening \\
\hline 213 & 63.2 & excellent & flexibility and tolerance \\
\hline 209 & 62.0 & excellent & empathy, insight \\
\hline 194 & 57.6 & good & awareness of own capacity \\
\hline 191 & 56.7 & good & use an online tool in career counselling \\
\hline 186 & 55.2 & good & awareness and appreciation of clients' cultural differences \\
\hline 171 & 50.7 & excellent & workplace wellness \\
\hline 162 & 48.1 & good & workplace wellness \\
\hline 148 & 43.9 & excellent & awareness and appreciation of clients' cultural differences \\
\hline 141 & 41.8 & excellent & awareness of own capacity \\
\hline 129 & 38.3 & excellent & use an online tool in career counselling \\
\hline 127 & 37.7 & good & empathy, insight \\
\hline 121 & 35.9 & good & flexibility and tolerance \\
\hline 102 & 30.3 & good & communication and listening \\
\hline 74 & 22.0 & good & observing ethical standards \\
\hline 17 & 5.0 & poor & use an online tool in career counselling \\
\hline 5 & 1.5 & poor & workplace wellness \\
\hline 3 & 0.9 & poor & awareness of own capacity \\
\hline 0 & 0.0 & poor & empathy, insight \\
\hline 0 & 0.0 & poor & communication and listening \\
\hline 0 & 0.0 & poor & flexibility and tolerance \\
\hline 0 & 0.0 & poor & observing ethical standards \\
\hline 0 & 0.0 & poor & awareness and appreciation of clients' cultural differences \\
\hline
\end{tabular}

Table 7

Crosstabs Chi-Square test of criteria Career information competences

\begin{tabular}{lccr}
\hline & Value & df & Asymp. Sig. (2-sided) \\
\hline Pearson Chi-Square & 61.471 & 2 & 0.000 \\
Likelihood Ratio & 62.235 & 2 & 0.000 \\
N of Valid Cases & 571 & & \\
\hline
\end{tabular}

The Pearson Chi-Square $p$-value $=0.000$ (Table 8 ), so the null hypothesis must be rejected and the alternative hypothesis accepted. In the criteria Career education competences is a relationship between Sub-competences sample and to what Extent sample.

Table 8

\section{Crosstabs Chi-Square test of criteria Career education competences}

\begin{tabular}{lccc}
\hline & Value & df & Asymp. Sig. (2-sided) \\
\hline Pearson Chi-Square & 55.320 & 6 & 0.000 \\
Likelihood Ratio & 59.993 & 6 & 0.000 \\
N of Valid Cases & 1338 & & \\
\hline
\end{tabular}

The Pearson Chi-Square p-value $=0.000$ (Table 9), so the null hypothesis must be rejected and the alternative hypothesis accepted. In the criteria Career counselling competences is a relationship between Sub-competences sample and to what Extent sample.

Table 9

Crosstabs Chi-Square test of criteria Career counselling competences

\begin{tabular}{lccc}
\hline & Value & df & Asymp. Sig. (2-sided) \\
\hline Pearson Chi-Square & 129.758 & 12 & 0.000 \\
Likelihood Ratio & 135.936 & 12 & 0.000 \\
N of Valid Cases & 2311 & & \\
\hline
\end{tabular}


The Pearson Chi-Square p-value $=0.000$ (Table 10), so the null hypothesis must be rejected and the alternative hypothesis accepted. In the criteria Career service managing competence is a relationship between Sub-competences sample and to what Extent sample.

Table 10

Crosstabs Chi-Square test of criteria Career service managing competence

\begin{tabular}{lccr}
\hline & Value & df & Asymp. Sig. (2-sided) \\
\hline Pearson Chi-Square & 73.202 & 8 & 0.000 \\
Likelihood Ratio & 75.736 & 8 & 0.000 \\
N of Valid Cases & 1667 & & \\
\hline
\end{tabular}

The Pearson Chi-Square p-value $=0.000$ (Table 11), so the null hypothesis must be rejected and the alternative hypothesis accepted. In the criteria Career service managing competence is a relationship between Sub-competences sample and to what Extent sample.

Table 11

Crosstabs Chi-Square test of criteria Generic competence

\begin{tabular}{lccr}
\hline & Value & df & Asymp. Sig. (2-sided) \\
\hline Pearson Chi-Square & 73.202 & 8 & 0.000 \\
Likelihood Ratio & 75.736 & 8 & 0.000 \\
N of Valid Cases & 1667 & & \\
\hline
\end{tabular}

Next, the frequency of respondent answers about the criteria for assessing the competence with relevant sub-competences were statistically analysed with the help of chi-square test, where the null hypothesis: the frequency of respondent answers is the same and the alternative hypothesis: the frequency of respondent answers not the same (Table 12-16).

Since the p-value (excellent) $=0.002<0.05$, p-value $($ good $)=0.000<0.05$, and p-value $($ poor $)=0.01$ is less than the significance level of $\alpha=0.05$ (Table 12), so the null hypothesis must be rejected and the alternative hypothesis accepted. The frequency of respondent answers is different. Statistically significant prevalence was: for the answer knowledge of updated information on educational and training at excellent choice (24.0), for the answer knowledge of updated information on employment trends, labour market, and social issues both at good (65.0) and poor choice (9.0).

Table 12

Chi-square test statistics of criteria Career information competences

\begin{tabular}{lcccc}
\hline \multicolumn{1}{c}{ Answers } & \multicolumn{2}{c}{ Residual } \\
\cline { 2 - 5 } & excellent & good & poor \\
\hline $\begin{array}{l}\text { knowledge of updated information on educational and training } \\
\text { knowledge of updated information on employment trends, }\end{array}$ & 24.0 & -65.0 & -9.0 \\
labour market, and social issues & -24.0 & 65.0 & 9.0 \\
\hline & Total & 240 & 302 & 30 \\
Chi-Square & 9.600 & 55.960 & 10.800 \\
df & 1 & 1 & 0.000 & 0.01 \\
\hline
\end{tabular}

Table 13

Chi-square test statistics of criteria Career education competences

\begin{tabular}{|c|c|c|c|}
\hline \multirow{2}{*}{ Answers } & \multicolumn{3}{|c|}{ Residual } \\
\hline & excellent & good & poor \\
\hline $\begin{array}{l}\text { to integrate the theory and research into practice in } \\
\text { guidance }\end{array}$ & -49.5 & 37.3 & 12.8 \\
\hline $\begin{array}{l}\text { to demonstrate the knowledge of lifelong career } \\
\text { development process }\end{array}$ & 29.5 & -18.8 & -10.3 \\
\hline to use the goal setting tasks in training & 3.5 & -3.8 & -0.3 \\
\hline to use career planning and decision making in training & 16.5 & -14.8 & -2.3 \\
\hline Total & 386 & 823 & 129 \\
\hline Chi-Square & 37.358 & 9.578 & 8.457 \\
\hline df & 3 & 3 & 3 \\
\hline Asymp. Sig. & 0.000 & 0.023 & 0.037 \\
\hline
\end{tabular}


Since the p-value $($ excellent $)=0.000<0.05$, p-value $($ good $)=0.023<0.05$, and $\mathrm{p}$-value $($ poor $)=0.037$ is less than the significance level of $\alpha=0.05$ (Table 13), so the null hypothesis must be rejected and the alternative hypothesis accepted. The frequency of respondent answers is different. Statistically significant prevalence was: for the answer to demonstrate the knowledge of lifelong career development process at excellent choice (29.5), for the answer to integrate the theory and research into practice in guidance both at good (37.3) and poor choice (12.8).

Since the p-value (excellent) $=0.000<0.05$, and p-value (poor) $=0.000<0.05$ (Table 14), so the null hypothesis must be rejected and the alternative hypothesis accepted. The frequency of respondent answers is different. Statistically significant prevalence was: for the answer ability to use of dialogue in career guidance at excellent choice (35.3), for the answer a multicultural career counselling poor choice (40.4). The p-value $($ good $)=0.070>0.05$, the null hypothesis can't be rejected. Thus, can be concluded that the frequency of respondent answers is the same.

Table 14

Chi-square test statistics of criteria Career counselling competences

\begin{tabular}{|c|c|c|c|}
\hline \multirow{2}{*}{ Answers } & \multicolumn{3}{|c|}{ Residual } \\
\hline & excellent & good & poor \\
\hline exploration competency & 0.3 & 18.1 & -17.6 \\
\hline selection and using of diagnostic methods & -28.7 & 21.1 & 7.4 \\
\hline use of counselling methods & 10.3 & -9.9 & 1.4 \\
\hline to be able to interact with a client in individual counselling & 27.3 & -30.9 & 0.4 \\
\hline to be able to interact with a client in group counselling & 11.3 & -2.9 & -8.6 \\
\hline ability to use of dialogue in career guidance & 35.3 & -10.9 & -23.6 \\
\hline a multicultural career counselling & -55.7 & 15.1 & 40.4 \\
\hline Total & 642 & 1308 & 361 \\
\hline Chi-Square & 67.072 & 11.671 & 50.992 \\
\hline $\mathrm{df}$ & 6 & 6 & 6 \\
\hline Asymp. Sig. & 0.000 & 0.070 & 0.000 \\
\hline
\end{tabular}

Since the p-value (excellent) $=0.000<0.05$, p-value (poor) $=0.000<0.05$ (Table 15), so the null hypothesis must be rejected and the alternative hypothesis accepted. The frequency of respondent answers is different. Statistically significant prevalence was: for the answer skills to cooperate effectively in a team of professionals at excellent choice (56.6), for the answer ability to implement a variety of career support models and programmes poor choice (35.6).

The p-value $($ good $)=0.349>0.05$, the null hypothesis can't be rejected. Thus, can be concluded that the frequency of respondent answers is the same.

Table 15

Chi-square test statistics of criteria Career service managing competence

\begin{tabular}{|c|c|c|c|}
\hline \multirow{2}{*}{ Answers } & \multicolumn{3}{|c|}{ Residual } \\
\hline & excellent & good & poor \\
\hline $\begin{array}{l}\text { ability to implement a variety of career support models and } \\
\text { programmes }\end{array}$ & -42.4 & 6.4 & 35.6 \\
\hline $\begin{array}{l}\text { ability to carry out a variety of career support models and } \\
\text { programmes }\end{array}$ & -27.4 & 12.4 & 14.6 \\
\hline skills to cooperate effectively in a team of professionals & 56.6 & -25.6 & -29.4 \\
\hline knowledge of (office) politics & 28.6 & 0.4 & -28.4 \\
\hline networking ability & -15.4 & 6.4 & 7.6 \\
\hline Total & 412 & 1003 & 252 \\
\hline Chi-Square & 82.612 & 4.443 & 63.675 \\
\hline df & 4 & 4 & 4 \\
\hline Asymp. Sig. & 0.000 & 0.349 & 0.000 \\
\hline
\end{tabular}

Since the p-value $\quad($ excellent $)=0.000<0.05, \quad$ p-value $\quad($ good $)=0.000<0.05, \quad$ p-value (poor) $=0.001<0.05$ (Table 16). So the null hypothesis must be rejected and the alternative hypothesis accepted. The frequency of respondent answers is different. Statistically significant prevalence was: for the answer observing ethical standards at excellent choice (73.5), for the answer awareness of own capacity (49.4), for the answer use an online tools in career counselling poor choice (8.7). 
Table 16

Chi-square test statistics of criteria Generic competence

\begin{tabular}{|c|c|c|c|}
\hline \multirow{2}{*}{ Answers } & \multicolumn{3}{|c|}{ Residual } \\
\hline & excellent & good & poor \\
\hline observing ethical standards & 73.5 & -70.6 & - \\
\hline communication and listening & 46.5 & -42.6 & - \\
\hline flexibility and tolerance & 24.5 & -23.6 & - \\
\hline empathy, insight & 20.5 & -17.6 & - \\
\hline awareness of own capacity & -47.5 & 49.4 & -5.3 \\
\hline use an online tools in career counselling & -59.5 & 46.4 & 8.7 \\
\hline awareness and appreciation of clients' cultural differences & -40.5 & 41.4 & - \\
\hline workplace wellness & -17.5 & 17.4 & -3.3 \\
\hline Total & 1508 & 1157 & 25 \\
\hline Chi-Square & 86.621 & 98.710 & 13.760 \\
\hline $\mathrm{df}$ & 7 & 7 & 2 \\
\hline Asymp. Sig. & 0.000 & 0.000 & 0.001 \\
\hline
\end{tabular}

\section{Conclusions}

It follows from all of the above that it is extremely important for a career counsellor to be qualified, to be a competent professional and to be able to apply the knowledge of the structure of the labour market and use the opportunities offered by the education system for doing professional work and help clients to take responsible career decisions. A career counsellor must be competent at all fields of competences: career information, career education, career counselling, career service managing and she/he must also possess generic competencies.

Analysing the results of study on career counsellors and school career counsellor's questionnaire the criteria visible in Table 1 for assessing the professional competence of career counsellors developed by authors were used. The criteria conclude 5 competence fields, each field having several sub-competences. Analysing the respondents' responses to excellent and good together, it can be concluded that the best developed sub-competencies on criteria Career information competences are knowledge of updated information on employment trends, labour market, and social issues $(\mathrm{n}=312$, $\mathrm{p}$-value $=0.000<0.05$, residual $=65.0$ ). The best developed sub-competences on criteria Career education competences are to demonstrate the knowledge of lifelong career development process $(\mathrm{n}=313, \mathrm{p}$-value $=0.000<0.05$, residual $=29.5)$ and to use career planning and decision making in training $(\mathrm{n}=304)$. The three most developed sub-competencies on criteria Career counselling competences are ability to use dialogue in career guidance $(\mathrm{n}=303, \mathrm{p}$-value $=0.000<0.05$, residual $=35.3)$, exploration competency $(\mathrm{n}=297)$ and use of counselling methods $(\mathrm{n}=279)$. The three most developed sub-competencies on criteria $\underline{\text { Career }}$ service managing competence are skills to cooperate effectively in a team of professionals $(\mathrm{n}=314$, $\mathrm{p}$-value $=0.000$, residual $=56.6)$, knowledge of $($ office $)$ politics $(\mathrm{n}=312)$, networking ability $(\mathrm{n}=274)$. The three most developed sub-competencies on criteria Generic competence are observing ethical standards $(\mathrm{n}=336$, $\mathrm{p}$-value $=0.000<0.05$, residual $=73.3)$, communication and listening $(\mathrm{n}=337)$ and empathy, insight $(\mathrm{n}=336)$. Competences that are needed to be improved demonstrated by respondents were: a multicultural career counselling $(27.3 \%)$ and ability to implement a variety of career support models and programmes $(25.5 \%)$. In general, it can be concluded that the professional competences of career counsellors and school career counsellors are sufficiently developed in Latvia.

\section{Bibliography}

1. Arhipova I., Bāliņa S. (2006). Statistika ekonomikā un biznesā [Statistics on Economics and Business]. Rīga: Datorzinību centrs. (in Latvian)

2. Axinte R. (2014). The School Counselor: Competencies in a Constructivist Model of Counseling for Career Development. Procedia - Social and Behavioral Sciences, 142, 255-259. doi: 10.1016/j.sbspro.2014.08.290

3. Bielecki J. (Ed.). (2013). Methods, techniques and tools to diagnose competences. Warsaw: National Centre for Supporting Vocational and Continuing Education. Retrieved from https://www.ess.gov.si/_files/5433/methods_techniques_and_tools.pdf 
4. Blank C. (2017). Skills for a Career Counselor. Chron. Retrieved from https://work.chron.com/skillscareer-counselor-1077.html

5. Bobu R., Soitu L. (2012). Competences and roles of career counsellors. In G.K. Zarifis, K. Martin., S. Sava (Eds.), International conference Back to Work-The Role of Validation of Competences in Professional Counselling of Adults. Thessaloniki, Greece: MEDIMOND, 1-4.

Retrieved from https://www.academia.edu/2364861/Back_to_Work-

The_Role_of_Validation_of_Competences_in_Professional_Counseling_of_Adults

6. Briska L., Dislere V. (2018). Guidance Model for Promoting Self-Directed Career Decision-Making by Secondary School Students. In V. Dislere (Ed.), The Proceedings of the International Scientific Conference Rural Environment. Education. Personality (REEP), 11. Jelgava: Latvia University of Life Sciences and Technologies, 344-353. doi: 10.22616/REEP.2018.042

7. Brizga D., Peks L. (2014). Workplace wellness and specialists' attitude to work safety. In V. Dislere (Ed.), The Proceedings of the International Scientific Conference Rural Environment. Education. Personality (REEP), 7. Jelgava: LLU, 90-96. Retrieved from https://lufb.llu.lv/conference/REEP/2014/Latvia-Univ-Agricult-REEP-2014proceedings-90-96.pdf

8. Francis-Smythe J., Haase S., Thomas E., Steele C. (2013). Development and Validation of the Career Competencies Indicator (CCI). Journal of Career Assessment, 21(2), 227-248. doi: $10.1177 / 1069072712466724$

9. Goodman-Scott E., Grothaus T. (2017). School Counselors' Roles in RAMP and PBIS: A Phenomenological Investigation (Part two). Professional School Counseling, 21(1), 130-141. doi: 10.5330/1096-2409-21.1.130

10. Gothard B., Mignot P., Offer M., Ruff M. (2001). Careers Guidance in Context. London: Sage Publications. doi: $10.4135 / 9781446220399$

11. Hanımoglu E. (2018). The perceptions of students about the role of school counsellors on career selection. European Journal of Educational Research, 7(4), 763-774. doi: 10.12973/eu-jer.7.4.763

12. Hiebert B., Neault R. (2014). Career Counselor Competencies and Standards: Differences and Similarities across Countries. Switzerland: Springer Link. doi: 10.1007/978-1-4614-9460-7_39

13. Jaunzeme I. (2011). Karjeras vadības un atbalsta sistēmas pilnveidošanas problēmas augstākajā izglīīibā Latvija [The Problems of Career Guidance System Improvement in Higher Education in Latvia]. (Doctoral Thesis, University of Latvia, Riga). https://dspace.lu.lv/dspace/handle/7/4591 (in Latvian)

14. Karataş K., Kaya I. (2015). An investigation of the perceptions of school administrators towards the roles and duties of school counsellors. Eurasian Journal of Educational Research, 61, 181-198. Retrieved from https://files.eric.ed.gov/fulltext/EJ1087612.pdf

15. Katsarov J., Lerkkanen J., Pouyaud J., Pukelis K. (2014). Coming to European Competence Standards for the Practice of Career Guidance and Counselling. Canterbury, UK: NICE. doi: 10.11588/nicenl.2014.0.16721

16. Mani P.S. (2020). Career Self-Management and Development of Multicultural Knowledge and Practice: Experience of Professional Counsellors. Canadian Journal of Family and Youth, 12(1), 124-146. doi: $10.29173 /$ cjfy 29494

17. Meijers F., Kuijpers M., Gundy C. (2013). The relationship between career competencies, career identity, motivation and quality of choice. International Journal for Educational and Vocational Guidance, 13(1), 47-66. doi: 10.1007/s10775-012-9237-4

18. Minimum Competencies for Multicultural Career Counselling and Development. (2009). National Career Development Association. Retrieved from

https://www.associationdatabase.com/aws/NCDA/asset_manager/get_file/9914/minimum_competen cies_for_multi-cultural_career_counseling.pdf?ver=21765

19. Network for Innovations in Career Guidance and Counselling in Europe (NICE). (2019). Retrieved from http://www.nice-network.eu/

20. Oertle K.M., O'Leary S. (2017). The importance of career development in constructing vocational rehabilitation transition policies and practices. Journal of Vocational Rehabilitation, 46(3), 407-423. doi:10.3233/JVR-170877

21. Orbé-Austin R. (2010). Multicultural Career Counseling Competence: 5 Key Tips for Improving Practice. Retrieved from

https://associationdatabase.com/aws/NCDA/pt/sd/news_article/28865/_PARENT/layout_details_cc/true

22. Patton W., McMahon M. (2014). Career development and systems theory: connecting theory and practice. Rotterdam, The Netherlands: Sense Publishers. 
23. Paura L., Arhipova I. (2002). Statistiskās neparametriskās metodes [Non-parametric statistical methods]. Jelgava: LLKC. (in Latvian)

24. Pavulens J. (2015). Career Management: Towards Constructivist Model. In V. Dislere (Ed.), Proceedings of the International Scientific Conference Rural Environment. Education. Personality (REEP), 8. Jelgava: LLU, 329-337. Retrieved from https://llufb.llu.lv/conference/REEP/2015/Latvia-Univ-Agricult-REEP2015proceedings-329-337.pdf

25. Phillips S.D., Christopher-Sisk E.K., Gravino K.L. (2001). Making Career Decisions in a Relational Context. The Counseling Psychologist, 29(2), 193-214. doi: 10.1177/0011000001292002

26. Racene A. (2017). Importance of Goal-Setting Tasks in Career Counselling. In V. Dislere (Ed.), The Proceedings of the International Scientific Conference Rural Environment. Education. Personalit (REEP), 10. Jelgava: LLU, 442-450. Retrieved from https://lufb.llu.lv/conference/REEP/2017/LatviaUniv-Agricult-REEP-2017_proceedings-442-450.pdf

27. Rācene A., Dislere V. (2014). Internet Tools as a Kind of Career E-Guidance. In V. Dislere (Ed.), The Proceedings of the International Scientific Conference Rural Environment. Education. Personality (REEP), 7. Jelgava: LLU, 200-207. Retrieved from https://llufb.llu.lv/conference/REEP/2014/LatviaUniv-Agricult-REEP-2014proceedings-200-207.pdf

28. Racene A., Dislere V. (2016). Didactic Model of Crisis Management for Women in Professional Crisis Situations. British Journal of Education, Society and Behavioural Science, 12(1). doi: 10.9734/BJESBS/2016/20619

29. Racene A., Dislere V. (2019). Choice of a Value Identification Method in Career Counselling. In V. Dislere (Ed.), the Proceedings of the International Scientific Conference Rural Environment. Education. Personality (REEP), 12. Jelgava: Latvia University of Life Sciences and Technologies, 289-296. doi: 10.22616/REEP.2019.038

30. Ranking Data in SPSS Statistics. (2020). Retrieved from https://statistics.laerd.com/spsstutorials/ranking-data-in-spss-statistics.php

31. Ridley C.R., Mollen D., Kelly S.M. (2011). Beyond Microskills: Toward a Model of Counseling Competence. The Counseling Psychologist, 39(6), 825-864. doi: 10.1177/0011000010378440

32. Savickas M.L. (2011). Career Counselling Washington: American Psychological Association.

33. Sharf R.S. (2014). Applying Career Development Theory to Counseling (6 ${ }^{\text {th }}$ ed.). Belmont, CA: Thomson Brooks/Cole.

34. Soika I. (2017). Evolution of Dialogue for Students' Career Guidance in Secondary Vocational Education. In V. Dislere (Ed.), The Proceedings of the International Scientific Conference Rural Environment. Education. Personality (REEP), 10. Jelgava: LLU, 481-488. Retrieved from https://llufb.llu.lv/conference/REEP/2017/Latvia-Univ-Agricult-REEP-2017_proceedings-481-488.pdf

35. Stăiculescu C., Livinţi R., Ștefan L.R., Todea S., Albu N. (2017). Managing the need for career guidance and counselling for students' case study - The Bucharest University of Economics Studies. Review of International Comparative Management / Revista De Management Comparat International, 18(2), 158-170. Retrieved from http://rmci.ase.ro/no18vol2/03.pdf

36. Urdzina-Merca I., Dislere V. (2018). Information and Communication Technology Based Career Guidance Model for Young People. In V. Dislere (Ed.), Proceedings of the International Scientific Conference Rural Environment, Education, Personality (REEP), 11. Jelgava: LLU, 406-415. doi: 10.22616/REEP.2018.050

37. Zhanguzhinova M.Y., Magauova A.S., Nauryzbaeva A.S. (2016). Competence Approach in Vocational Education of Kazakhstan in Conditions of Innovational and Industrial Development of the Society. In V. Dislere (Ed.), The Proceedings of the International Scientific Conference Rural Environment. Education. Personality (REEP), 9, Jelgava: LLU, 128-133. Retrieved from https://lufb.llu.lv/conference/REEP/2016/Latvia-Univ-Agricult-REEP-2016proceed2255-808X-128-133.pdf

38. What does a career counsellor do? (2019). Career Explorer. Retrieved from https://www.careerexplorer.com/careers/career-counselor/ 